\title{
Democratizing Global Economic Governance
}

James K. Boyce

Political Economy Research Institute

\section{Publisher's Note}

This is an electronic version of an article published in Development and Change: complete citation information for the final version of the paper, as published in the print edition of Development and Change, is available on the Blackwell Synergy online delivery service, accessible via the journal's website at:

http://www.blackwellpublishing.com/journal.asp?ref $=00$ 12-155X\&site $=1$

or

http://www.blackwell-synergy.com 


\section{Democratizing Global Economic Governance}

\section{James K. Boyce}

\section{INTRODUCTION}

The globalization of the world economy has been an uneven process: the integration of markets has outpaced the integration of governance, and governance for the protection of capital has outpaced governance for the protection of human well-being. In his essay, 'Economic Globalization and Institutions of Global Governance', Keith Griffin (2003a) addresses both these asymmetries, and concludes that 'we need to invent mechanisms that will enable global institutions to be held accountable to people worldwide for their performance' (ibid.: 805). I agree.

The need for democratic governance of the global economy is increasingly apparent to growing numbers of people around the world. This is a core goal of the diffuse popular movement that is often labelled 'anti-globalization' and more accurately described as a movement for global justice. In the political arena, global justice requires a more equitable distribution of power; in the economic arena, it requires a more equitable distribution of wealth and income. The problem, of course, is how to get from here to there.

In this comment, I discuss three of Keith Griffin's recommendations. The first is his insistence, in common with many economists, that trade policy instruments should 'almost never' be used to protect the environment. The second is his endorsement of the creation of United Nations 'peace enforcement' units, a step proposed by UN Secretary-General Boutros-Ghali in 1995. The third is his suggestion that the World Bank be scrapped and replaced by a tax-and-transfer scheme that would redistribute income automatically from rich countries to poor countries. I conclude with some thoughts on what 'democratization' means, and why it is important.

\section{TRADE POLICY AND THE ENVIRONMENT}

The argument that trade policy should not be used to protect the environment is based on the premise that 'environmental externalities should be tackled at their source, which is usually at the point of production, and occasionally at the point of consumption, but rarely at the point of exchange' (Griffin, 2003a: 798). As an example of the proper approach, 
Griffin observes that international efforts to protect endangered whale species did not ban trade in whale products, but instead imposed a ban on whale harvests, enforced by the International Whaling Commission. Just as national-level environmental problems are the responsibility of environmental agencies rather than trade ministries, so at the international level 'environmental externalities that have transnational implications' should be addressed by the United Nations Environment Programme (UNEP) rather than the World Trade Organization (WTO).

This logic is compelling, until we face two facts. First, UNEP is a toothless organization whose mandate is limited to provision of information and assistance. The institution's lack of enforcement powers is no accident, but rather a deliberate design. It is fine to maintain that 'we should reform UNEP' - if, among other things, reform includes a full set of tooth implants - but this is unlikely to come about anytime soon. In the meantime, those who seek to defend environmental quality must seize the opportunities created by actually existing institutions. The relevant institutions include not only UNEP but also the WTO, international trade agreements, treaties that address specific environmental problems (the Convention for the Regulation of Whaling is an example), and civil-society networks whose 'informal governance' complements formal institutions (Boyce, 2004). Important though it may be to strengthen UNEP, it would be a strategic mistake to rely on a single horse to pull the environmental-governance cart.

Second, national-level environmental policies are seldom optimal (however optimality is defined). Instead they are refracted through political processes. Policy outcomes reflect disparities in political power between those who benefit from externalization of environmental costs and those who bear the resulting environmental burdens. The globalization of markets creates scope for 'ecological dumping': the sale of products at prices below their marginal social cost by virtue of externalization of environmental costs. In such circumstances, even localized externalities can have transnational implications, and a case can be made for countervailing trade policies. Discussions of environmental problems tend to focus on negative externalities in the forms of pollution and natural resource depletion. But positive externalities environmental benefits that are not rewarded by the market - are also of great importance. At the global level, a prime example is the conservation of genetic diversity in rice, maize, wheat and other crops, a vital environmental service that underpins long-term food security (Brush, 2003). In the absence of international mechanisms to reward the farmers who sustain this diversity most of whom are poor rural families in the global South - a case again can be made for policies that depart from free-trade axioms.

The claim that trade policy ought to be divorced from environmental concerns is analogous to the claim that policies to promote economic growth ought to be divorced from distributional concerns. In principle, lump-sum redistribution may be the most efficient way to achieve a more equitable distribution of income. But in practice, growth and distribution 
are interwoven, a point Keith Griffin has made forcefully on many occasions (see, for example, Griffin, 2003b). Trade policy and the environment are interwoven, too.

\section{PEACE ENFORCEMENT}

I now turn to what Griffin (2003a: 799) rightly terms 'the most basic public good of all - security, conflict resolution and peace'. I share his view that 'global peace should be subsidized and placed under international leadership, not left to an individual state to act as policeman of the world, or even to a coalition of states'. To this end, the proposal to create armed UN units for 'peace enforcement' deserves serious discussion.

Two issues warrant further thought. The first, again, is what to do in the meantime - in the period between now and a future that could prove to be rather distant. In the absence of a UN peace-enforcement capability, should all military interventions by individual states or coalitions be renounced? Or should they be judged on a case-by-case basis? When the UN failed to intervene to prevent the 1994 Rwandan genocide, should individual states have done so? Griffin (ibid.: 790) recalls US Senator J. William Fulbright's 1966 warning against 'the arrogance of power' - a warning too little heeded both in Fulbright's time and today. But the tragedies of the 1990s in Rwanda and other places, such as East Timor and the former Yugoslavia, compel us to recognize that the arrogance of power can take the form of inaction as well as action. ${ }^{1}$ In writing that the intervention in Kosovo 'established the principle that human rights supersede, or at least qualify, the sovereign rights of states', Griffin (ibid.: 802) touches on this issue.

The second question is the extent to which the creation of a UN force would suffice to secure the global public good of peace. Griffin notes two additional requirements: a system of global taxation to finance this and other global public goods, and a larger role for democratic decision-making at the UN and other international institutions so as to confer legitimacy in the eyes of the world's people. On top of these daunting challenges, we also must come to grips with the ways that war and peace are interwoven with other matters - including economic growth, the distribution of wealth and income, international trade, and the environment - in the fabric of public policy. Economic policies that neglect 'horizontal' inequalities across lines of region, ethnicity, race, or religion, for example, can fuel social tensions that precipitate violent conflict (Stewart, 2000). Or, to cite another example, tariff reductions pushed by the international financial institutions in the name of trade liberalization can deprive governments of revenues desperately needed for peacebuilding in 'postconflict' countries (Boyce, 2002).

1. The problem predates the 1990s. For discussion, see Power (2002). 
For these reasons, responsibility for the provision of the global public good of peace cannot be delegated to a specialized agency. As in the case of environmental quality, global governance for peace and security must involve a network of existing and prospective international institutions.

\section{THE WORLD BANK AND CREDIT ALLOCATION}

Lastly, I turn to Griffin's (2003a: 803) call to abolish the World Bank on the grounds that it is 'an institution that no longer serves a useful purpose'. Having long criticized the Bank - among other things for its inattention to distributional outcomes, its role in the creation of odious debts, the adverse environmental impacts of many of its projects, and its reluctance to reshape economic policy to the needs of peacebuilding ${ }^{2}$ - I do not wish to be mistaken as an apologist for that institution. I believe, however, that the solution to the World Bank's many flaws is not to dismantle it, but to democratize it.

Credit allocation is a basic task of governance. Finance cannot be left entirely to financial markets, because the markets fail to take account of externalities, both positive and negative, generated by investment. For this reason, national governments use credit allocation policies to alter the patterns of lending that would result from the 'free play' of market forces. These policies include lending by public-sector institutions at below-market rates (as well as regulations and incentives to guide private-sector lending). In the United States, for example, a government-sponsored enterprise called the Federal National Mortgage Association (popularly known as Fannie Mae) is a major source of housing finance (D'Arista and Boyce, 2002).

At the international level, public-sector lending functions are performed by the World Bank and other multilateral development banks. The ways these institutions allocate credit often leaves much to be desired. The defect lies not in the idea of credit allocation, however, but rather in the governance of these institutions. One important step toward more democratic governance of the international financial institutions would be to loosen the link between financial contributions and voting power. As an alternative to the current plutocratic distribution of voting power, Griffin (2003a: 802) suggests a population-weighted scheme based on the principle of one person, one vote. In theory, this would be more democratic than the current set-up. But in practice, whether this is so would depend on the degree to which the national governments that presumably would continue to cast votes on behalf of their citizens are themselves democratic. The sad truth is that democratic deficits are not confined to the international financial institutions.

2. See, for example, Boyce (1993), Boyce (2002) and Hartmann and Boyce (1983), 
Griffin (2003a: 804) proposes that the World Bank be replaced by 'a tax and transfer mechanism under which funds would be raised by a compulsory, progressive tax on the GNPs of rich countries and distributed automatically to poor countries, with the amount received varying inversely with a country's per capita income'. Leaving aside the feasibility of such a scheme, some misgivings may be voiced as to its desirability. Would unconditional transfers of cash to the Abachas and Marcoses of the world really be an advance over the status quo? Is the principle of conditionality inherently objectionable, or is the problem how conditionality is implemented in practice? If the former, this effectively rules out credit allocation as a tool of global governance, since by definition it makes access to funds conditional on the uses to which they are put. If, however, the problem is that the conditions are inappropriate or applied inconsistently, then we should change the governance bathwater instead of throwing out the credit-allocation baby.

\section{DEMOCRACY: FORM AND SUBSTANCE}

Democracy is not simply a question of institutional architecture - elections, laws, and organizational structures. It is also a question of how political power is distributed within society. Formal democratization involves the growth of institutions that foster voice and accountability. Substantive democratization involves movement toward a more egalitarian distribution of power.

Form matters. For democracy to flourish, institutions must ensure that ordinary citizens can voice their demands and that decision-makers can be held accountable to those who are affected by their decisions. Given the inevitable imperfections of institutions and the inexorable temptations of power, a resilient democracy needs to have checks and balances built into the architecture of governance - for example, an independent judiciary. This need for checks and balances, along with the interdependence among policy domains noted above, tempers the efficiency argument for clear-cut divisions of administrative labour. The tasks of global governance cannot be parcelled out neatly amongst international agencies. Instead there is much to recommend an alternative model of multi-layered governance based on the emergence of 'diffuse networks of diverse actors performing multiple and overlapping functions' (Haas, 2004).

Substance matters, too. Even with formal democratic institutions, the distribution of power in a society can remain quite inequitable. Eligible voters may not participate in elections, or their preferences may be manipulated by propaganda. Various sorts of 'influence peddling' may make governance resemble a market where voice is defined by purchasing power, and accountability is to patrons rather than the public at large. In particular, there are bound to be tensions between the equitable distribution of political 
power and the inequitable distribution of wealth. Although formal democracy is necessary for substantive democracy, it is not sufficient.

Democratic governance is important both as a means to other ends such as economic growth and equity, and as an end in itself. In a speech after the terrible Chinese famine of 1959-61, Mao Zedong put the instrumental case for democracy as follows: 'Without democracy, you have no understanding of what is happening down below; the situation will be unclear; you will be unable to collect sufficient opinions from all sides; there can be no communication between top and bottom; top-level organs of leadership will depend on one-sided and incorrect material to decide issues.. ${ }^{3}$ As Amartya Sen (1984: 503) has observed, the history of famines demonstrates that the instrumental role of democracy can be 'very crucial to matters of life and death'. Yet, as Sen has also argued, democracy also has intrinsic value as an element of human freedom (Sen, 1999).

Democratization is an historic process that takes generations. At the national level it remains incomplete more than two centuries after the French Revolution proclaimed the goals of liberté, egalité, fraternité. At the global level it is just beginning. Keith Griffin's essay invites us to confront some of the most important issues of our time: the building of new global institutions, the demolition and rehabilitation of old ones, the division of labour among international agencies, and the allocation of voting power within them. The process by which these issues are tackled will do much to determine the nature of the outcome. History teaches us that the creation of democratic institutions requires the democratic creation of institutions. It is fitting, therefore, that the democratization of global governance should be a topic of wide and vigorous debate in these pages and elsewhere.

\section{REFERENCES}

Boyce, James K. (1993) The Philippines: The Political Economy of Growth and Impoverishment in the Marcos Era. London: Macmillan.

Boyce, James K. (2002) Investing in Peace: Aid and Conditionality after Civil Wars. Adelphi Paper No 351. Oxford: Oxford University Press.

Boyce, James K. (2004) 'Green and Brown? Globalization and the Environment', Oxford Review of Economic Policy (forthcoming).

Brush, Stephen B. (2003) 'The Lighthouse and the Potato: Internalizing the Value of Crop Genetic Diversity', in J. K. Boyce and B. G. Shelley (eds) Natural Assets: Democratizing Environmental Ownership, pp. 187-205. Washington, DC: Island Press.

D'Arista, Jane and James K. Boyce (2002) 'Where Credit is Due: Allocating Credit to Advance Environmental Goals', Challenge 45(3): 58-82.

Griffin, Keith (2003a) 'Economic Globalization and Institutions of Global Governance', Development and Change 34(5): 789-807.

Griffin, Keith (2003b) 'A Witness of Two Revolutions', Distinguished Humanist Achievement Lecture, University of California, Riverside. Available online at: http://repositories.cdlib.org/ cgi $/$ viewcontent.cgi?article $=1000 \&$ context $=$ cis .

3. Quoted in Sen (1984: 503). 
Haas, Peter (2004) 'Confronting the Global Governance Deficit'. Amherst, MA: University of Massachusetts, Department of Political Science (unpublished paper).

Hartmann, Betsy and James K. Boyce (1983) A Quiet Violence: View from a Bangladesh Village. London: Zed Books.

Power, Samantha (2002) 'A Problem from Hell': America and the Age of Genocide. New York: Basic Books.

Sen, Amartya (1984) Resources, Values and Development. Oxford: Basil Blackwell.

Sen, Amartya (1999) Development as Freedom. New York: Alfred A. Knopf.

Stewart, Frances (2000) 'Crisis Prevention: Tacking Horizontal Inequalities', Oxford Development Studies 28(3): 245-62.

James K. Boyce teaches economics at the University of Massachusetts, Amherst (Amherst, MA 01003, USA) and directs the programme on development, peacebuilding, and the environment at the Political Economy Research Institute (http://www.umass.edu/peri/dpe.html). 